\title{
PENGELOLAAN ZAKAT OLEH BADAN DAN LEMBAGA AMIL ZAKAT DI SURABAYA DAN GRESIK*
}

\author{
Indah Purbasari** \\ Bagian Hukum Islam Fakultas Hukum Universitas Trunojoyo Madura, Bangkalan \\ Jalan Raya Telang Kamal, Bangkalan, Jawa Timur 69162
}

\begin{abstract}
This research aims to explore potency of corporate zakat in Surabaya and Gresik. This research is a socio legal research. Those two regions were chosen due to industrial basis. The research found that the empowerment is only of zakat focused on the individual zakat. Government corporation and islamic banking distribute corporate social responsibility fund but they don't distribute zakat from their corporations. The potency of corporate zakat is certainly bigger. Therefore, this research suggested regulation model to optimalize the empowerment of individual and corporate zakat due to Law Nnumber 23 of 2011 on The Management of Zakat regulated only the management body of zakat, but not as an obligation.
\end{abstract}

Keywords: empowerment, zakat, company, regulation.

\section{Intisari}

Penelitian ini bertujuan untuk menggali potensi zakat perusahaan di Surabaya dan Gresik, dengan metode penelitian sosio legal. Kedua wilayah ini dipilih sebagai basis industri. Hasil penelitian ini menunjukkan bahwa pemberdayaan zakat masih berorientasi pada zakat individu. Perusahaan BUMN maupun bank syariah menyalurkan dana tanggung jawab sosial perusahaan tetapi tidak menyalurkan zakat perusahaannya, padahal potensi zakat perusahaan tentunya lebih besar. Oleh karena itu, model regulasi pengelolaan zakat diperlukan untuk mengoptimalkan pemberdayaan zakat baik individu maupun perusahaan sebab UndangUndang Pengelolaan Zakat hanya mengatur manajemen zakat, bukan pada kewajiban menunaikannya.

Kata Kunci: pemberdayaan, zakat, perusahaan, regulasi.

\section{Pokok Muatan}

A. Latar Belakang 69

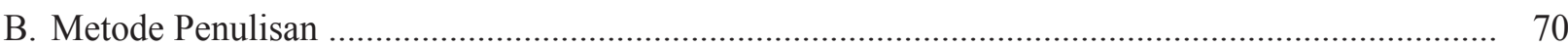

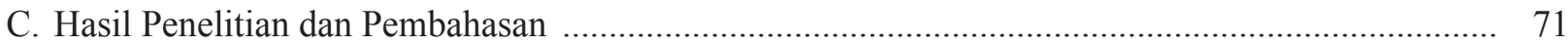

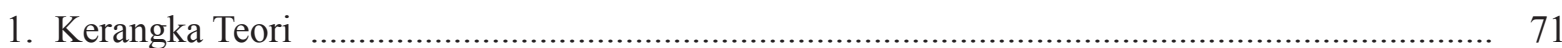

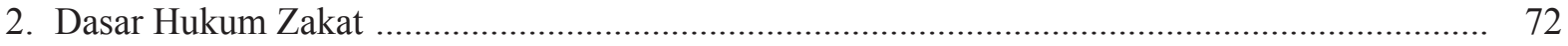

3. Harta yang Dikenai Zakat dan Golongan Penerima Zakat .................................................... 73

4. Gambaran Umum Pengelolaan Zakat oleh Badan Amil Zakat Nasional (BAZNAS) dan Lembaga Amil Zakat di Wilayah Surabaya dan Gresik ........................................................ 74

5. Pengelolaan Zakat Penghasilan oleh Badan Amil Zakat dan Lembaga Amil Zakat .................. 76

6. Pengelolaan Zakat Perusahaan Berbasis Syariah ….............................................................. 78

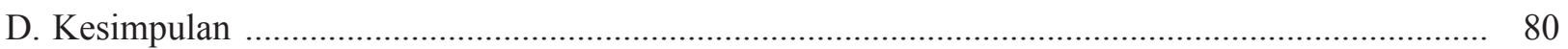

Hasil Penelitian Hibah Bersaing yang didanai oleh DP2M Dikti Tahun Anggaran 2013

Alamat korespondensi: myifa09@gmaisl.com 


\section{A. Latar Belakang Masalah}

Suatu negara dikatakan berhasil dalam pembangunan jika ia mampu menekan angka kemiskinan. Taraf kesejahteraan suatu negara akan berpengaruh di kancah internasional. Oleh karena itu, memerangi kemiskinan merupakan tantangan yang dihadapi oleh setiap negara. Tingkat kemiskinan di suatu Negara akan mempengaruhi apakah negara tersebut termasuk negara maju, berkembang ataukah miskin. Dengan kata lain, tingkat kesejahteraan suatu negara dipengaruhi oleh besarnya prosentase kemiskinan di negara tersebut. Kondisi inilah yang memotivasi bersaing meningkatkan kesejahteraan termasuk Indonesia.

Menyejahterakan kehidupan bangsa merupakan tujuan nasional yang diamanahkan dalam Pembukaan Undang-Undang Dasar Republik Indonesia alinea keempat. Pembangunan di segala bidang diupayakan Pemerintah Indonesia untuk meningkatkan kesejahteraan penduduk. Namun, upaya ini tidak didukung dengan optimalisasi pelaksanaan peraturan perundang-undangan yang memiliki visi pemerataan pendapatan dan peningkatan kesejahteraan, seperti Undang-Undang Nomor 38 Tahun 1999 tentang Pengelolaan Zakat (selanjutnya disebut Undang-Undang Pengelolaan Zakat) yang diundangkan pasca krisis ekonomi 1998 dan diperbaharui dengan Undang-Undang Nomor 23 Tahun 2011 tentang Pengelolaan Zakat (selanjutnya disebut Undang-Undang Pengelolaan Zakat).

Krisis ekonomi 1998 merupakan bukti nyata jatuhnya ekonomi yang berbasis riba. Fakta bertahannya bank syariah pada masa krisis menginspirasi pemerintah Indonesia untuk memberdayakan instrumen Hukum Ekonomi Islam yang berbasis pada perdagangan, larangan riba, pemberdayaan zakat. Pemberlakuan undangundang zakat ini diharapkan dapat menjadi sumber dana yang potensial untuk kesejahteraan umum yang secara hakiki merupakan fungsi zakat dalam hukum ekonomi islam. Oleh karena itu, pemerintah pun perlu mendukung peningkatan efektifitas pelaksanaan undang-undang ini bukan hanya pada ranah zakat perorangan namun juga zakat perusahaan. Saat ini, pemberdayaan masih berorientasi pada zakat perorangan padahal zakat perusahaan tentunya berpotensi ekonomis yang lebih besar.

Oleh karena itu, penelitian ini dilakukan karena memiliki arti penting dalam pengembangan wacana dan penerapan hukum ekonomi Islam di Indonesia khususnya dalam upaya pengentasan kemiskinan. Pengembangan hukum ekonomi Islam di Indonesia saat ini cenderung berfokus pada ranah perdagangan atau bisnis syariah. Maknanya, aspek yang dikembangkan cenderung pada aspek komersial. Harus diakui bahwa konsep Hukum Ekonomi Islam menekankan perdagangan sebagai sektor riil yang menjadi penyangga utama perputaran. Namun, perlu diperhatikan pula bahwa ekonomi Islam disangga tiga pilar yakni perdagangan, larangan riba dan pemberdayaan zakat. Dengan kata lain, hukum ekonomi islam tidak hanya menekankan pada aspek komersial (perdagangan) melainkan didukung pula dengan sistem keuangan yang tidak berbasis bunga (riba) dan pemberdayaan zakat yang bertujuan untuk pemerataan pendapatan dan pengentasan kemiskinan. Jika aspek bisnis dan sistem keuangan di Indonesia mulai menerapkan konsep yang bebas riba, sayangnya tidak diikuti dengan konsep pemberdayaan zakat yang efektif. Oleh karena itu, penelitian ini memiliki kontribusi penting untuk menciptakan pola keseimbangan dalam sistem ekonomi agar tidak hanya membangun aspek komersial tetapi juga semestinya menciptakan sistem pemerataan pendapatan dan pembangunan potensi ekonomi masyarakat melalui konsep zakat.

Pemerataan pendapatan melalui konsep zakat berbasis pada penyisihan sebagian harta yang dimiliki seseorang untuk diberikan kepada orangorang yang membutuhkan. Zakat wajib hukumnya atas setiap muslim. Zakat terdiri atas zakat fitrah yang dibayarkan pada Bulan Ramadhan sebelum berupa bahan makanan pokok dan zakat maal yakni harta harta yang dimiliki sesuai dengan nisab (jumlah) dan haul kadar (waktu) tertentu. Hukum Islam mengatur tujuh golongan penerima zakat yang 
disebut mustahik zakat. Mustahik zakat ini yang utama adalah fakir dan miskin. Dengan kata lain, Hukum Islam sangat memperhatikan pemenuhan kebutuhan orang-orang yang tidak mampu (fakir dan miskin) agar tidak terjadi kesenjangan ekonomi dan sosial. Hukum zakatlah yang menjembatani antara orang yang memiliki harta agar menyisihkan sebagian pendapatannya untuk orang yang tidak dapat mencukupi secara ekonomis.

Oleh karena itu, perlu diciptakan konstruksi hukum yang tepat untuk optimalisasi penarikan dan penyaluran zakat kepada pihak-pihak yang menjadi obyek penerima zakat. Harus diperhatikan pula, penyaluran zakat yang merupakan bentuk pemerataan pendapatan ini perlu dikelola dengan baik agar tidak menimbulkan ketergantungan. Artinya, santunan ini bukanlah sekedar pola menengadahkan tangan ke atas untuk menerima dari pihak pemberi dan penerima mempergunakan untuk kepentingan konsumtif. Zakat yang diberikan haruslah berfungsi sebagai motivasi untuk meningkatkan taraf kehidupan lebih baik.

Adapun rumusan masalah yang diangkat pada penelitian ini yang pertama adalah bagaimana pemberdayaan zakat baik zakat perorangan maupun perusahaan oleh Badan Amil Zakat Nasional dan lembaga amil zakat di wilayah Surabaya dan Gresik setelah berlakunya Undang-Undang Pengelolaan Zakat? Dan yang kedua yakni bagaimana zakat perusahaan yang dikelola oleh lembaga amil zakat di bawah BUMN dan bank syariah? Berdasarkan rumusan tersebut dijabarkan melalui tujuan penelitian dijabarkan sebagai berikut: Pertama, memperoleh data mengenai segmentasi wajib zakat dan pengelolaan dana zakat setelah berlakunya Undang-Undang Pengelolaan zakat oleh Badan Amil Zakat Nasional Provinsi Jawa Timur dan Lembaga Amil Zakat di Wilayah Surabaya dan Gresik. Kedua, mendapatkan informasi mengenai potensi dana zakat yang dikelola oleh perusahaan yakni Lembaga Amil Zakat di lingkungan Bank
Muamalat Indonesia Kantor Cabang Surabaya, Bank Tabungan Syariah Cabang Surabaya dan PT Semen Indonesia, Gresik.

\section{B. Metode Penulisan}

Penelitian ini bertujuan untuk merancang model kebijakan dan kerangka hukum yang dapat digunakan untuk memberdayakan zakat dan menemukan model penerapan yang efektif untuk pemberdayaan zakat dalam upaya pengentasan kemiskinan. Oleh karena itu, jenis penelitian yang tepat digunakan adalah penelitian sosio perundangundangan atau sering disebut dengan socio-legal research. Penelitian sosio perundang-undangan (socio-legal research) ini termasuk kategori penelitian non-doktrinal (non-doctrinal research) artinya penelitian ini tidak hanya berfokus pada penafsiran peraturan perundang-undangan melainkan membahas bagaimana hukum ini berlaku pada konteks kemasyarakatan. Dengan kata lain, penelitian sosio perundang-undangan (sociolegal research) mengabungkan penelitian hukum dengan investigasi permasalahan-permasalahan sosial. Tujuannya adalah menjajaki apakah suatu kaidah hukum dianggap sudah cukup mewadahi permasalahan sosial yang ada, mengkaji instrumen hukum yang diperlukan masyarakat, menguji efektifitas jalannya suatu peraturan perundangundangan, memberikan masukan berkaitan dengan peraturan perundang-undangan yang ada apakah dapat menjadi sarana kontrol atau perubahan perilaku. ${ }^{1}$

Pendekatan kualitatif dipilih untuk mencapai tujuan penelitian sebab informasi yang disajikan menekankan pada deskripsi fakta empiris yang terjadi dari masyarakat dan memusatkan pada gejala-gejala sosial yang alami terjadi dan perspektif yang masyarakat secara alami berkembang. ${ }^{2}$ Lokasi Penelitian adalah di Surabaya sebagai ibukota Provinsi Jawa Timur dan Gresik sebagai pusat industri. Informan kunci penelitian ini adalah 
Pengurus Badan Amil Zakat Nasional Jawa Timur dan Gresik; Pengurus Lembaga Amil Zakat: Baitul Maal Hidayatullah, Yayasan Dana Sosial Al-Falah; dan Pengurus Lembaga Amil Zakat dalam lingkup perusahaan: Bank Muamalat Indonesia Cabang Surabaya, PT Bank Tabungan Negara Syariah Cabang Surabaya, PT Semen Indonesia, Gresik.

Sumber data meliputi data primer dan sekunder. Data primer merupakan data langsung yang diperoleh di lapangan. Data di lapangan ini meliputi data yang diperoleh dari Badan Amil Zakat (BAZ) dan Lembaga Amil Zakat (BAZ), instansi pemerintah, perusahaan. Perusahaan yang dipilih adalah perusahaan berbasis syariah dan sebagai komparasi adalah BUMN dan/atau perusahaan swasta. Data sekunder merupakan data pendukung yang berupa peraturan perundang-undangan, bukubuku, jurnal, penelitian sebelumnya, media massa.

Data yang telah dikumpulkan akan diolah memalui beberapa tahapan. Tahap pertama yakni editing. Editing merupakan tahapan memilah-milah bahan dan data telah terkumpul untuk dipilih yang relevan dengan tujuan. Tahapan selanjutannya adalah coding dan classifying. Tahapan ini bertujuan memberi kode dan mengelompokkan data berdasarkan tujuannya. ${ }^{3}$ Selanjutnya data akan dianalisis secara induktif yakni umum ke khusus dengan metode deskriptif analitis dan ekstensifikasi (pengembangan penafsiran peraturan perundangundangan.

\section{Hasil Penelitian dan Pembahasan \\ 1. Kerangka Teori}

Muhammad Syafi'iAntonio mengkategorikan "Islam adalah suatu dien” (agama/jalan kehidupan). Sebagai dien, Islam memuat tuntunan yang menyeluruh baik dalam sisi ibadah maupun hubungan sesama manusia. sosial (muammalah). Ibadah berfungsi menjaga keseimbangan hubungan manusia dengan penciptanya. Adapun interaksi sosial diatur melalui aspek muammalah. ${ }^{4}$ Dalam konteks muammalah ini, Eddy Asnawi menyatakan bahwa Islam memberi garis besar pengaturan untuk manusia dalam interaksi dengan lingkungannya yang mengacu kepada prinsip-prinsip dasar yakni keadilan, musyawarah, persaudaraan, kebebasan dan persamaan. ${ }^{5}$ Oleh karena itu, dapat disimpulkan bahwa konteks muammalah bersifat universal, terbuka (tidak terbatas bagi muslim, dapat diterapkan pula pada non-muslim) dan membuka peluang penafsiran yang fleksibel. Fleksibilitas ruang lingkup muammalah menjadikan prinsipprinsipnya cenderung diterapkan di sektor publik. Pengembangan konsep muammalah saat ini cenderung pada konsep ekonomi, bisnis (perdagangan) dan sistem keuangan yang berbasis syariah. ${ }^{6}$

Zainal Arifin menjelaskan pembangunan sistem Islam berdasarkan prinsip larangan alikhtinaz (larangan menimbun harta) dan prinsip ta'awun (tolong menolong). ${ }^{7}$ Prinsip melarang mendiamkan (menimbun) harta sehingga menjadikan harta tersebut tidak produktif. Artinya, sektor ekonomi harus didorong melalui perputaran harta yang produktif melalui sektor perdagangan. Prinsip ta'awun (tolong menolong) diwujudkan salah satunya melalui konsep zakat yakni kewajiban umat Islam menyisihkan sebagian hartanya untuk orang yang berhak menerimanya. Sementara itu, Heri Sudharsono menegaskan bahwa legitimasi hukum zakat ini sangatlah kuat yakni tiga puluh kali disebut dalam Al-Quran dan dua puluh tujuh kali disebut bersamaan dengan perintah sholat yakni "Dirikan sholat dan tunaikan zakat". ${ }^{8}$ Maknanya, kedudukan

\footnotetext{
Bambang Sunggono, 2005, Metode Penelitian Hukum, Raja Grafindo Persada, Bandung, hlm.125-126.

Muhammad. Syafi'i Antonio, 2001, Bank Syariah: Dari Teori ke Praktik, Gema Insani Press dan Tazkia Cendikia, Jakarta, hlm. 4

Eddy Asnawi, "Prinsip Bernegara dalam Islam", dalam Jurnal Hukum Respublika: Menegakan Demokrasi dan Keadilan, Vol. 9, No. 1, Desember 2009, hlm. 83.

Indah Purbasari, "The Implementation of Akad Wadiah and Mudharabah in Islamic Banking of Indonesia and Malaysia", dalam Rechtidee: Jurnal Hukum, Vol. 6, No. 2, Desember 2010, hlm. 34.

Zainul Arifin, 2002, Dasar-Dasar Manajemen Bank Syariah, Alfabet, Jakarta, hlm. 3.

Heri Sudharsono, 2003, Bank dan Lembaga Keuangan Syariah:Deskripsi dan Ilustrasi, Ekonisia, Yogyakarta, hlm. 232.
} 
zakat ini sejajar dengan perintah sholat. Jika sholat adalah ibadah vertikal, antara manusia dengan penciptanya (habluminallah), zakat merupakan ibadah horizontal, antara manusia dengan manusia (habbluminannaas). Pelaksanaan dua jenis ibadah ini akan menciptakan keseimbangan antara ibadah kepada Allah dan interaksi sesama manusia.

Peran zakat dalam interaksi sesama manusia (muammalah) ditegaskan oleh Norhaziah binti Nawai dan Ainulashikin binti Marzuki dalam penelitiannya, bahwa "Zakat merupakan salah satu pendapatan negara yang mempunyai fungsi sosial untuk mengurangi kesenjangan antara kelompok ekonomi kaya dan miskin". Falsafah yang menjadi dasar adalah segala kekayaan yang ada di bumi ini tidak lain milik Allah sehingga seorang muslim tidak boleh hanya memikirkan kepentingannya sendiri melainkan harus memiliki kepekaan sosial bagi orang yang membutuhkan. Oleh karena itu, setiap muslim wajib membayar zakat maal (harta) sebesar 2,5\% dari kekayaannya untuk orang-orang yang memerlukan. Potensi zakat maal ini sangatlah besar untuk penerimaan negara sehingga upaya mengoptimalisasi pengumpulan dan penyaluran zakat ini sangatlah diperlukan untuk pembangunan sumber daya manusia, pengentasan kemiskinan dan pembangunan sosial. ${ }^{9}$ Pentingnya pemberdayaan zakat maal ini juga ditegaskan oleh Suhaila Abdul Hamid. Pemerintah Malaysia menyadari besarnya potensi zakat maal dengan mendorong individual Muslim Malaysia untuk membayarkan zakat maalnya melalui baitul maal. Pemberian intentif pajak juga digalakkan bagi muslim yang membayarkan zakatnya. ${ }^{10}$
Potensi zakat maal ini juga menjadi perhatian Pemerintah Indonesia. Hal ini tertuang dalam penjelasan Undang-Undang Nomor 38 Tahun 1999 tentang Pengelolaan Zakat yang menyatakan bahwa peraturan perundang-undangan ini dibentuk untuk mengoptimalkan potensi zakat sebagai pemasukan Negara dan untuk pengentasan kemiskinan. Oleh karena itulah, Afdol memberikan pendapatnya bahwa hukum zakat termasuk dalam kerangka hukum positif Indonesia baik dalam UndangUndang Pengelolaan Zakat maupun UndangUndang Pengadilan Agama. ${ }^{11}$ Pernyataan ini didukung oleh Encik Muhammad Fauzan dan Indah Purbasari dimana keduanya memiliki kesamaan pandangan bahwa meskipun Indonesia tidak mengakui secara tegas bahwa Indonesia berdasarkan agama tertentu, Hukum Islam telah menjadi bagian integral dari hukum positif di Indonesia yang ditunjukkan dengan pemberlakuan Hukum Islam di Indonesia tidak hanya seputar hukum keluarga namun telah berkembang pada lapangan Hukum Ekonomi Islam, termasuk pengaturan zakat. ${ }^{12}$

\section{Dasar Hukum Zakat}

Zakat secara etimologis berasal dari kata zaka artinya, "berkah, bersih, dan baik." Zaka dapat pula "berarti tumbuh dan berkembang". ${ }^{13}$ Secara terminologi, zakat berarti "Sejumlah harta tertentu yang diwajibkan Allah diserahkan pada orang-orang yang berhak". ${ }^{14}$ Berdasarkan dua pengertian tersebut dapat disimpulkan bahwa zakat merupakan harta yang wajib dikeluarkan oleh setiap muslim untuk membersihkan ataupun menyucikan hartanya agar harta yang dimiliki menjadi berkah. Mengeluarkan zakat bukanlah mengurangi harta, akan tetapi terus

\footnotetext{
Norhaziah Binti Nawai dan Ainulashikin Binti Marzuki, "The Role of Zakat in Developing Muslim Economy", dalam Nik Salida Sulaiha Nik Saleh (Ed.), 2007, The Developmet of Economics and Muammalat Practices, Penerbit Universiti Sains Islam Malaysia (USIM), Bandar Baru Nilai, hlm.1.

10 Suhaila Abdul Hamid, "The Zakat and Tax Practices for Individuals in Malaysia", dalam Nik Salida Sulaiha Nik Saleh (Ed.), 2007, The Developmet of Economics and Muammalat Practices, Penerbit Universiti Sains Islam Malaysia (USIM), Bandar Baru Nilai, hlm. 18 dan 23.

11 Afdol, 2006, Kewenangan Pengadilan Agama Berdasarkan Undang-Undang No. 3 Tahun 2006 \& Legislasi Hukum Islam di Indonesia, Airlangga Universiti Press, Surabaya, hlm. 117.

12 Encik Muhammad Fauzan, "The Dilemma of The Position of Islamic Law and Its Existence in Indonesia Legal System", Rechtidee: Jurnal Hukum, Vol. 6, No. 1, Juli 2010, hlm. 74. Lihat juga Indah Purbasari, "Resurrection of Islamic Law in Indonesia", Rechtidee: Jurnal Hukum, Vol. 2, No. 2, Desember 2007, hlm. 85.

13 Yusuf Qardawi, Hukum Zakat: Studi Komparatif Mengenai Status dan Filsafat Zakat Berdasarkan Qur'an dan Hadis (terj.: Salamun Harun, dkk), Pustaka Litera Antar Nusa dan Mizan, Bogor, hlm. 34

14 Ibid.
} 
berkembang dalam konteks kebajikan dan ibadah.

Landasan hukum zakat terdapat dalam AlQuran Surat At-Taubah ayat 18 yang berbunyi bahwa, "Sungguh, yang menyemarakkan masjidmasjid Allah hanyalah orang-orang yang beriman kepada Allah dan hari kemudian, mendirikan salat, membayar zakat, dan tiada takut kepada siapa-siapa kecuali Allah [....]". ${ }^{15}$ Selain itu, hukum zakat juga tertuang dalam Al-Quran Surat At-Taubah ayat 71 yang terjemahanya berbunyi, "Orang-orang Mu'minin dan Mu'minat lindung-melindungi satu sama lain. Mereka menganjurkan yang makruf dan melarang yang mungkar, serta mendirikan salat, menunaikan zakat dan menaati Allah dan RasulNya [....]". ${ }^{16}$ Dasar hukum zakat juga ditegaskan dalam Al-Quran Surat At-Taubah ayat 103, bahwa "Pungut zakat dari kekayaan mereka, berarti kau membersihkan dan mensucikan mereka dengan zakat itu, kemudian doakanlah mereka, doamu itu sungguh memberikan kedamaian buat mereka: Allah Maha Mendengar, Maha Mengetahui". ${ }^{17}$ Ketiga ayat ini menegaskan hukum zakat atas diri tiap muslim yang hukumnya sejajar dengan sholat, menegakkan kebenaran dan mencegah kemungkaran serta menegaskan tujuan zakat untuk menyucikan harta.

Kewajiban zakat ini diakomodasi pengaturan pelaksanaannya di Indonesia melalui UndangUndang Pengelolaan Zakat di mana tujuan pengelolaan zakat adalah meningkatkan pelayanan pengelolaan zakat yang efektif dan efisien serta pemanfaatan zakat dalam upaya pengentasan kemiskinan dan peningkatan kesejahteraan. ${ }^{18}$ Pengelolaan zakat ditangani oleh Badan Amil Zakat Nasional yang dikoordinasi pemerintah ${ }^{19}$ dan Lembaga Amil Zakat yang diprakarsai pengelolaanya secara swadaya masyarakat. ${ }^{20}$

\section{Harta yang Dikenai Zakat dan Golongan Penerima Zakat}

Zakat pada masa Rasulullah SAW merupakan kewajiban agama yang atas diri setiap muslim dan menjadi salah satu pilar pembangunan agama dan ekonomi Islam. Pada masa pemerintahan Umar bin Khatab, zakat juga diposisikan sebagai pendapatan utama negara Islam dan menjadi ukuran fiskal utama untuk memecahkan permasalahan ekonomi secara keseluruhan. Umar bin Khatab juga menegaskan denda yang berat yakni sebesar $50 \%$ bagi orang yang tidak mau membayar zakat. Muslim yang tidak mengeluarkan zakat akan diberikan denda yang berat. ${ }^{21}$ Hal ini menunjukkan betapa pentingnya zakat untuk kemaslahatan umat Islam pada masa itu dan dijadikan sarana untuk memecahkan masalah ekonomi secara keseluruhan pada masa itu.

Posisi zakat sebagai pendapatan utama negara berakhir pada masa kekhalifahan Islam. Pendapatan negara umumnya termasuk Indonesia didapatkan dari sektor pajak. Oleh karena itu, Indonesia mencoba menggali potensi zakat melalui Undang-Undang Pengelolaan Zakat. UndangUndang Pengelolaan Zakat mendefinisikan "Zakat adalah harta yang wajib dikeluarkan oleh seorang muslim atau badan usaha untuk diberikan kepada yang berhak menerimanya sesuai dengan syariah Islam". ${ }^{22}$ Berdasarkan definisi tersebut zakat dapat dikenakan kepada perorangan muslim dan badan usaha. Zakat yang wajib dibayarkan umat Islam terdiri atas zakat nafs yang disebut juga dengan zakat fitrah yang merupakan zakat pribadi yang dikeluarkan pada saat bulan ramadhan sebelum sholat ied dan zakat maal (harta) yakni kewajiban mengeluarkan sejumlah harta benda tertentu

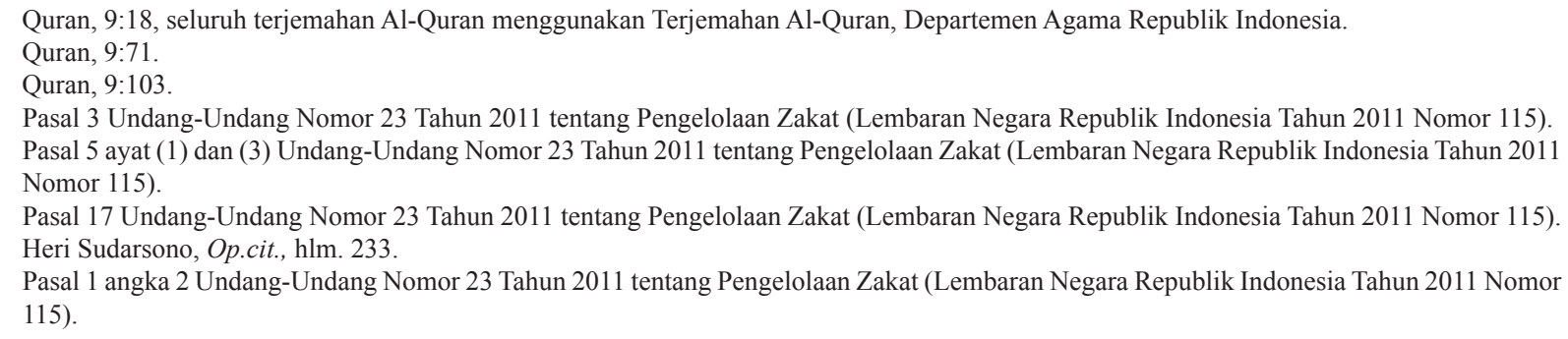


untuk membersihkan kekayaan dan menyucikan pemiliknya. Harta yang wajib dizakati menurut Undang-Undang Pengelolaan Zakat adalah simpanan logam mulia berupa emas, perak atau logam mulia lainnya, kekayaan berupa uang dan surat berharga, pendapatan dari hasil perdagangan, perusahaan pertanian, perkebunan, kehutanan perikanan, peternakan, pertambangan, pendapatan dan jasa, rikaz. ${ }^{23}$ Harta zakat yang terkumpul akan didistribusikan pada 8 (delapan) asnaf/golongan orang yang berhak menerima zakat (disebut dengan mustahik zakat), yang terdiri atas: (1) fakir yakni orang-orang yang masih dalam usia produktif (usianya diatas 17 tahun) yang telah bekerja tetapi hasilnya tidak dapat mencukupi kebutuhan hidup sehari-hari; (2) miskin yakni orang-orang yang masih dalam usia produktif dan masih memiliki alat produksi akan tetapi masih dalam kekurangan; (3) amil yakni orang-orang yang memiliki profesi mengumpulkan dan membagikan zakat; (4) muallaf yakni orang-orang yang baru masuk Islam atau orang-orang yang lemah imannya sehingga belum mengeluarkan zakat; (5) riqab yakni orang-orang yang sedang terbelenggu akan tetapi tetap bertahan dengan harga dirinya; (6) ghorimin yakni orangorang yang memiliki hutang ataupun orang-orang yang dalam keadaan pailit; (7) sabilillah yakni orang-orang yang dalam keadaan berdakwah dan memberikan pendidikan Islam tanpa ada dukungan dari pemerintah; dan (8) ibnu sabil yakni orangorang yang dalam proses belajar agama Islam maupun umum yang tidak ada dukungan dari pemerintah. ${ }^{24}$

\section{Gambaran Umum Pengelolaan Zakat oleh Badan Amil Zakat Nasional (BAZNAS) dan Lembaga Amil Zakat di Wilayah Surabaya dan Gresik}

Undang-Undang Pengelolaan Zakat mengatur bahwa pengelolaan zakat dilakukan oleh badan amil zakat nasional dan lembaga amil zakat. ${ }^{25} \mathrm{Pe}$ ngaturan pendirian lembaga pengelolaan zakat memang penting mengingat potensi zakat di Indonesia yang mayoritas penduduknya beragama Islam tentulah besar. Lembaga pengelola zakat ini dalam Undang-Undang a quo disebutkan dengan istilah Badan Amil Zakat dan Lembaga Amil Zakat.

Badan Amil Zakat Nasional (selanjutnya disingkat BAZNAS) merupakan organisasi yang mengelola zakat yang dibentuk oleh pemerintah. BAZNAS berkedudukan di tiap-tiap kabupaten/ kota. Salah satu BAZNAS yang berdiri di tingkat provinsi, kota dan kabupaten adalah BAZNAS Jawa Timur (Jatim), BAZNAS Surabaya dan BAZNAS Kabupaten Gresik. Rata-rata yang membayarkan zakat di BAZNAS yakni, pejabat, birokrat, Pegawai Negeri Sipil (PNS) di lingkungan pemerintah kabupaten/kota. ${ }^{26}$ Mekanisme pembayaran zakat penghasilan (zakat maal) dapat dilakukan dengan potong gaji langsung dengan persetujuan dari PNS ataupun pembayaran langsung secara sukarela oleh PNS yang bersangkutan. Meskipun segmen utama BAZNAS adalah pejabat dan pegawai di lingkungan pemerintah daerah, BAZNAS juga menerima zakat yang dibayarkan masyarakat umum. Kenyataannya, tidak semua PNS menyalurkan zakatnya melalui BAZNAS. Kendala ini terjadi karena kesadaran membayar zakat yang kurang dan tingkat kepercayaan pada BAZNAS sebagai badan resmi pemerintah sering dikaitkan dengan masih rendahnya tata kelola pemerintahan yang bersih (good governance). Hal ini berpengaruh pada segmen penerimaan BAZNAS meskipun data statistik menunjukkan penerimaan BAZNAS juga tidak sedikit. Berdasarkan data di BAZNAS Jatim,

Pasal 4 ayat (2) Undang-Undang Nomor 23 Tahun 2011 tentang Pengelolaan Zakat (Lembaran Negara Republik Indonesia tahun 2011 Nomor 115).

24 Amiruddin Inoed, et al., 2005, Anatomi Fiqh Zakat: Potret \& Pemahaman Badan Amil Zakat Sumatera Selatan, Pustaka Pelajar, Yogyakarta, hlm. 35-38.

25 Pasal 1 angka 2 Undang-Undang Nomor 23 Tahun 2011 tentang Pengelolaan Zakat (Lembaran Negara Republik Indonesia tahun 2011 Nomor 115).

26 Tri Apriliyanto, 2007, Pelaksanaan Pertanggungjawaban Badan Amil Zakat Kota Surabaya dalam Pengolahan Zakat: Tinjauan UU No. 38 Tahun 1999 Tentang Pengolahan Zakat, Skripsi, Fakultas Hukum Universitas Trunojoyo, Bangkalan, hlm. 43. Didukung oleh keterangan yang diperoleh dari Pengurus Badan Amil Zakat Nasional Jawa Timur, 15 September 2013. 
Potensi penerimaan zakat di Jawa Timur tahun 2012 mencapai Rp13.359.000,00. ${ }^{27}$

Berbeda dengan BAZNAS yang dikelola oleh pemerintah, Lembaga Amil Zakat (selanjutnya disingkat LAZ) adalah organisasi yang mengelola zakat yang dibentuk oleh masyarakat untuk mendukung pemberdayaan zakat oleh BAZNAS. LAZ dipersyaratkan terdaftar sebagai organisasi kemasyarakatan Islam yang bergerak di bidang pendidikan, dakwah dan sosial, berbentuk badan hukum umumnya yayasan dan mendapat persetujuan dari
BAZNAS ${ }^{28}$ Eksistensi BAZNAS dan LAZ tidak boleh diartikan terjadinya persaingan dalam mendapatkan mustahik zakat. Persaingan dalam hal ini boleh diartikan sebagai fastabiqul khoirot (berlomba-lomba dalam kebaikan) dengan cara mengajak orang menunaikan rukun Islam yang ketiga yakni membayar zakat. Persinggungan segmen pembayar zakat memang dapat terjadi namun tidak pada segmentasi utama. Profil lembaga sekaligus segmentasi wajib zakat di gambarkan pada Tabel di bawah sebagaimana berikut:

Tabel 1.

Pengelolaan Segmentasi Subyek ZIS pada BAZNAS dan LAZ yang Menjadi Obyek Penelitian di Wilayah Surabaya dan Gresik ${ }^{29}$

No. Nama BAZNAS dan LAZ

1. BAZNAS Jawa Timur, Gedung Islamic Centre Surabaya, Jalan Raya Dukuh Kupang Surabaya, Ketua: Saifullah Yusuf.

2. LAZ Baitul Maal Hidayatullah Surabaya, Jalan Raya Mulyosari Surabaya, Kepala Cabang: Supendi.

3. LAZ Yayasan Dana Sosial Al-Falah, J1. Raya Darmo Surabaya, Ketua: Mahmud Zaki.

4. LAZ Bank Muammalat Indonesia.

5. LAZ Bank Tabungan Negara Syariah.

6. LAZ PT Semen Indonesia Gresik.

\section{Segmentasi Wajib Zakat dan Donatur ZIS}

Mengelola zakat fitrah dan mal, infak, sedekah dari wajib zakat/donatur perseorangan. Segmentasi: birokrat, pejabat, Pegawai Negeri Sipil (PNS) di lingkungan pemerintah daerah (provinsi/kabupaten/kota), masyarakat umum.

Mengelola zakat fitrah dan mal, infak, sedekah dari wajib zakat/donatur perseorangan. Segmentasi: Masyarakat umum baik PNS, karyawan swasta, wisausaha.

Mengelola zakat fitrah dan mal, infak, sedekah dari wajib zakat/donatur perseorangan. Segmentasi: jamaah Masjid Al-Falah, santri Masjid Al-Falah, orang tua/wali santri dari Sekolah Al-Falah dan masyarakat umum.

Mengelola zakat fitrah dan mal, infak, sedekah dari wajib zakat/donatur perseorangan. Segmentasi: direksi, karyawan dan nasabah bank.

Mengelola zakat fitrah dan mal, infak, sedekah dari wajib zakat/donatur perseorangan. Segmentasi: direksi, karyawan dan nasabah bank.

Mengelola zakat fitrah dan mal, infak, sedekah dari wajib zakat/donatur perseorangan. Segmentasi: Direksi dan Karyawan PT Semen Indonesia.

Sumber: Hasil wawancara dengan BAZNAS Jawa Timur dan Pengurus Lembaga Amil Zakat Baitul Maal Hidayatullah, Yayasan Dana Sosial Al-Falah Surabaya, Bank Muamalat Indonesia Kantor Cabang Darmo Surabaya, BTN Syariah Kantor Cabang Surabaya, PT Semen Indonesia Gresik, Tahun 2013.

Pusat Badan Amil Zakat Nasional, "Laporan Rekapitulasi Penerimaan Zakat Per Oktober 2012”, pusat.baznas.go.id/wpcontent/uploads/ downloads/2012/10/laporanrekapitulasipenerimaanzakat.pdf, diakses 1 November 2013.

28 Pasal 17 dan 18 Undang-Undang Nomor 23 Tahun 2011 tentang Pengelolaan Zakat (Lembaran Negara Republik Indonesia tahun 2011 Nomor 115).

29 Tabel dibuat berdasarkan kesimpulan hasil wawancara dengan Pengurus BAZNAS Jawa Timur dan Pengurus Lembaga Amil Zakat Baitul Maal Hidayatullah, Yayasan Dana Sosial Al-Falah Surabaya, Bank Muamalat Indonesia Kantor Cabang Darmo Surabaya, BTN Syariah Kantor Cabang Surabaya, PT Semen Indonesia Gresik, dalam rentang waktu penelitian Juli-Oktober 2013. 
Tabel di atas merupakan gambaran hasil penelitian yang menunjukkan segmen utama penarikan zakat BAZNAS adalah pada pejabat dan/ atau birokrat di lingkungan pemerintah propinsi, kota atau kabupaten (sebagaimana telah disebutkan di atas), sedangkan segmen LAZ adalah masyarakat umum. Selain berbeda dari segi mustahik, segmen penyaluran BAZNAS dan LAZ juga berbeda. Penyaluran BAZNAS umumnya didistribusikan bersinergi dengan program pemerintah sementara LAZ biasanya bersinergi dengan kegiatan inti lembaga induk dan pemberdayaan masyarakat. Selain itu, LAZ umumnya bersinergi dengan kegiatan pesantren, masjid, yayasan anak yatim ${ }^{30}$ dan dalam perkembangannya terdapat LAZ yang berbasis perusahaan swasta dan Badan Usaha Milik Negara (BUMN).

LAZ Baitul Maal Hidayatullah (BMH) berdiri di bawah Yayasan Hidayatullah yang menaungi kegiatan utama dakwah, pendidikan sekolah berbasis Islam (Islamic boarding school), pesantren. Upaya meningkatkan pendapatan zakat dilakukan BMH dengan cara jemput zakat yakni amil (petugas penarik zakat) ditugaskan untuk menggali potensi zakat melalui donatur tetap dan melayani pembayaran zakat dengan mendatangi ke rumah dan/atau kantor. Layanan ini berlaku untuk zakat, infak, sedekah (ZIS).

LAZ Masjid Al-Falah mempunyai nama resmi Yayasan Dana Sosial Al-Falah (YDSF). YDSF mengelola masjid dan lembaga pendidikan Al-Falah. YDSF juga memiliki metode jemput zakat yang berbeda dengan BMH. YDSF membuka kounter kecil di pusat-pusat pembelanjaan. Tujuan pembukaan kounter adalah meningkatkan kesadaran umat Islam untuk menunaikan kewajiban zakat tidak sekedar memenuhi konsumtif di pusat perbelanjaan. ${ }^{31}$

Pengelolaan zakat oleh LAZ tidak hanya oleh pemerintah (melalui BAZNAS) dan swadaya masyarakat. Perusahaan juga mulai merintis berdirinya LAZ. Hal ini ditunjukkan dengan pendirian LAZ Bank Muamalat Indonesia (LAZ BMI), LAZ Bank Tabungan Negara Syariah (BTN Syariah), LAZ PT Semen Indonesia dengan segmen donatur adalah direksi dan karyawan serta nasabah (bank). ${ }^{32}$

\section{Pengelolaan Zakat Penghasilan oleh Badan Amil Zakat dan Lembaga Amil Zakat}

Sebagaimana dijelaskan sebelumnya, Pengelolaan Undang-undang Zakat di Indonesia diwadahi oleh Badan Amil Zakat (BAZNAS) dan Lembaga Amil Zakat (LAZ). Institusi pengelolaan ini sesuai dengan ketentuan Undang-Undang Pengelolaan Zakat. Sayangnya Undang-Undang ini lebih mengutamakan pengaturan pengelolaan zakat tetapi tidak menekankan pada kewajiban pembayaran zakat bagi umat Islam. Jika pengaturan kewajiban ini diwadahi, tentunya menjadi potensi zakat pengelolaan ekonomi yang cukup besar.

Potensi zakat yang dimaksud adalah berkaitan dengan mayoritas penduduk Indonesia beragama Islam. Jika Undang-Undang Zakat ini diiringi pengaturan mengenai mekanisme kewajiban membayar zakat bagi Muslim tentunya menjadi potensi pemasukan negara yang besar. Sayangnya, Pemerintah Indonesia lebih sering mengampanyekan peningkatan kesadaran pembayaran daripada kesadaran membayar zakat. Kampanye zakat lebih banyak dilakukan Lembaga Amil Zakat, yang mayoritas dilakukan di bulan Ramadhan.

Berdasarkan Tabel 1 digambarkan mayoritas dana ZIS yang dikelola oleh BAZNAS dan LAZ di wilayah Surabaya dan Gresik berasal dari ZIS pribadi. Dana ZIS ini dikelola oleh BAZNAS dan LAZ untuk berbagai program baik di bidang

30 Keterangan Benny Nur, Pengurus BAZNAS Jawa Timur menegaskan keterangan Saifullah Yusuf, Ketua BAZNAS Jawa Timur, 25 Agustus 2013.

31 Hasil Observasi terhadap metode penarikan zakat Yayasan Dana Sosial Al-Falah Surabaya, dalam rentang waktu Juli-Oktober 2013.

32 Disimpulkan berdasarkan pengamatan langsung (observasi) dan keterangan Pengurus Lembaga Amil Zakat Bank Muammalat Indonesia Kantor Cabang Darmo Surabaya, BTN Syariah Kantor Cabang Surabaya dan PT Semen Indonesia, Gresik, data penelitian September-Oktober 2013. 
pendidikan, pemberdayaan ekonomi, peningkatan aktivitas dakwah dan/atau bantuan kemanusiaan. BAZNAS dan LAZ memiliki keleluasaan untuk mendistribusikan dana infak dan sedekah untuk program-program tersebut namun pengelolaan dana zakat memiliki aturan tersendiri. Pengaturan yang dimaksud mencakup baik penerimaan maupun penyaluran. Pertama, donatur harus jelas akad dana yang diberikan apakah untuk keperluan zakat maal atau infaq dan shadaqah sebab penyalurannya berbeda. Selanjutnya, amil dan donatur akan melakukan ijab kabul (serah terima) dan diakhiri dengan mendoakan donatur ZIS. Permasalahannya donatur sering tidak menyebutkan secara jelas akad penyerahan dana ini diperuntukkan tujuan zakat, infak, sedekah, atau wakaf produktif. Mereka cenderung menyerahkan pada lembaga amil zakat akan dikategorikan zakat, infak, sedekah. Padahal ketiganya mempunyai konsekuensi hukum yang berbeda. Hukum zakat adalah wajib yang artinya jika tidak ditunaikan berdosa sementara hukum infak dan sedekah adalah sunah sehingga pemberi infak dan sedekah akan diberi pahala lebih jika melaksanakannya. Permasalahan ini terjadi karena kurang pahamnya donatur mengenai hukum menafkahkan harta dan konsekuensinya. Oleh karena itu, amil akan berupaya menjelaskan dan menegaskan kembali status dana yang dibayarkan. ${ }^{33}$

Setelah dana diserahterimakan, amil akan mendistribusikan berdasarkan akad awal penyerahan apakah zakat, infak atau sedekah. Penyaluran dana infak dan sedekah didistribusikan pada program lembaga baik pendidikan, kemanusiaan, pemberdayaan ekonomi ataupun dakwah. Adapun penyaluran zakat ini dikontrol dengan standar yang jelas dan harus memenuhi kriteria delapan asnaf ini, tidak boleh diperuntukkan yang lain sebab distribusi zakat telah diatur dalam hukum Islam. ${ }^{34}$ Dengan kata lain zakat harus didistribusikan untuk kepentingan delapan asnaf (golongan) yang wajib menerima zakat (mustahiq zakat) yakni fakir, miskin, amil, muallaf, riqab, gharim, sabilillah, ibnu sabil yang diatur dalam Al-Quran. ${ }^{35}$ Penyaluran zakat untuk kepentingan umum dimungkinkan dalam skala terbatas yakni dalam konteks sabilillah yakni kepentingan perjuangan dan/atau kemaslahatan umat selama tidak dibiayai cukup oleh pemerintah. Namun, kepentingan fisabilillah ini adalah urutan ketujuh di antara para mustahik. Dana beasiswa dapat pula diberikan dengan catatan masuk salah satu kategori dari delapan asnaf tersebut.

Meskipun penerimaan zakat oleh BAZNAS dan LAZ cenderung meningkat tiap tahunnya, upaya pemerintah dalam mendorong masyarakat membayar zakat belum optimal. Kenyataannya, Pemerintah terus berupaya mengampanyekan kesadaran membayar pajak dan mendorong masyarakat memiliki Nomor Pokok Wajib Pajak (NPWP) pribadi, memberi insentif pajak berupa pemotongan persentase pajak jika memiliki NPWP. Namun, pemerintah tidak pernah mengampanyekan sadar zakat bagi umat Islam. Kampanye sadar zakat justru dilakukan oleh Lembaga Amil Zakat. Akibatnya, umat Islam yang bertindak sebagai muzakki (pembayar zakat) merasa dibebani dua kewajiban sekaligus. Kewajiban tersebut meliputi membayar zakat sebagi perintah agama dan membayar zakat sebagai kewajiban warga negara. Pelaksanaan pemberian insentif pajak atas dasar pembayaran zakat belum berjalan maksimal sebab insentif pajak atas zakat dapat diberikan asalkan zakat dibayarkan melalui BAZNAS bukan LAZ. Padahal, kendala utama penyaluran zakat melalui BAZNAS adalah segmentasinya adalah pejabat, birokrat, PNS dan masih rendahnya kepercayaan masyarakat pada BAZNAS akibat kurangnya tata kelola pemerintahan yang bersih. Selain itu, belum jelas pula apakah zakat yang dibayarkan masuk kas negara atau kas BAZNAS. Jika masuk dalam kas BAZNAS artinya penerimaan zakat tidak dimasukkan pada penerimaan negara. Artinya, Pemerintah Indonesia belum serius mendorong

\footnotetext{
Wawancara dengan Supendi, Pengurus Baitul Maal Hidayatullah Surabaya, 5 September 2013

Wawancara dengan Supendi, Kepala Baitul Maal Hidayatullah Surabaya, 5 September 2013.

Definisi masing-masing mustahik terdapat di Bab II.
} 
umat Islam untuk membayar zakat (tidak hanya pajak) sekaligus menjadikan potensi pengumpulan zakat sebagai penghasilan negara.

\section{Pengelolaan Zakat Perusahaan Berbasis Syariah}

Pembahasan sebelumnya menjelaskan bahwa segmen donatur zakat BAZNAS dan LAZ masih bertumpu pada zakat penghasilan individu. Padahal secara besaran, zakat badan usaha, badan hukum, atau perusahaan tentunya lebih besar daripada besaran zakat penghasilan pribadi. Dua isu dalam hal zakat perusahaan ini mengenai subyek perusahaan yang wajib membayar zakat dan mekanisme pembayaran zakat.

Isu yang pertama berkenaan dengan kategori perusahaan yang menjadi subyek zakat. Zakat hanya wajib bagi setiap muslim. Jika diterapkan dalam konteks perusahaan, subyek zakat adalah pemilik perusahaan. Hal ini dikaitkan dengan prinsip bahwa setiap harta yang diperoleh dari usaha apapun wajib dialokasikan sebesar 2,5\% untuk zakat. Penghasilan perusahaan dalam hal ini masuk dalam kategori zakat perniagaan (perdagangan). Pertanyaannya adalah apakah semua perusahaan dapat dikenai wajib zakat. Hukum zakat dikenai pada setiap muslim. Jika dikaitkan dengan perniagaan, perniagaan ini tentunya harus dijalankan oleh Muslim atau berbadan hukum yang menjalankan prinsip syariah. Dengan kata lain, perusahaan yang wajib mengeluarkan zakat adalah perusahaan yang dimiliki oleh muslim dan/ atau perusahaan tersebut beroperasi secara syariah. Berdasarkan konteks awal mengenai perusahaan yang wajib dikenai zakat, kategori perusahaan yang berbadan hukum yang dapat dijadikan wajib zakat dalam konteks perkembangan perkembangan hukum ekonomi Islam di Indonesia saat ini adalah perusahaan/institusi keuangan syariah seperi bank syariah, asuransi takaful, kopersi syariah dan/atau Baitul Maal Wa Tamwil. Institusi keuangan syariah tersebut sebagaimana dijelaskan sebelumnya terikat pada prinsip larangan riba serta kewajiban membayar zakat. Oleh karena itu, wajib zakat perusahaan yang dipilih dalam penelitian ini adalah bank syariah. Hal ini didasari pertimbangan bahwa bank syariah yang memiliki landasan hukum positif yang jelas berdasarkan Undang-Undang Republik Indonesia Nomor 21 Tahun 2008 tentang Perbankan Syariah. Selain itu, perkembangan bank syariah yang cukup pesat di Indonesia diiringi dengan eksistensi LAZ yang dikelola oleh bank syariah sehingga pengelolaan zakat perusahaan perlu menjadi perhatian.

Namun, hasil penelitian menunjukkan baik BAZNAS Jawa Timur, LAZ BMH Surabaya dan LAZ YDSF tidak pernah menerima penyaluran zakat perusahaan baik perusahaan milik negara (BUMN), perusahaan daerah (BUMN) dan/atau institusi keuangan syariah. ${ }^{36}$ Pengurus BAZNAS dan LAZ berpendapat bahwa zakat perusahaan bank syariah ataupun perusahaan lainnya dikelola sendiri secara internal. ${ }^{37}$ Pendapat pengurus BAZNAS Jawa Timur dan LAZ BMH Surabaya dan YDSF justru bertolak belakang dengan data yang dihimpun dari segmentasi donatur ZIS dalam Tabel 1 di atas. Kenyataannya, LAZ BMI dan LAZ BTN tetapi fungsinya menyalurkan zakat individu nasabah dan karyawan bank bukan zakat badan hukumnya. Hal ini terjadi pula pada LAZ PT Semen Indonesia, Gresik yang segmen utama donatur ZIS adalah direksi dan karyawan perusahaan. Hal ini menarik untuk dicermati sebab LAZ di bawah perusahaan sebaiknya berkonsentrasi mengelola dana zakat perusahaan bukan hanya mengelola zakat individu. Ketika hal ini coba diminta penjelasan pada pengurus LAZ di bawah perusahaan, pendirian LAZ di bawah perusahaan memang tidak ditujukan untuk pengelolaan dana zakat perusahaan. LAZ bank syariah ditujukan untuk menampung zakat bagi hasil ataupun zakat sukarela yang dibayar nasabah demikian pula LAZ PT Semen Indonesia, Gresik yang memang ditujukan mendorong

Data Laporan Tahunan BAZNAS JawaTimur dan Yayasan Dana Sosial Al-Falah Surabaya, Tahun 2012.

Disimpulkan berdasarkan data dan keterangan wawancara dengan pengurus BAZNAS Jawa Timur, LAZ Baitul Maal Hidayatullah Surabaya, September-Okteber 2013 
kesadaran karyawan untuk membayar zakat, infaq dam shodaqoh. Namun, pengurus LAZ PT Semen Indonesia dan LAZ BMI dan BTN Syariah mengakui turut serta mengelola sebagai dari dana Corporate Social Responsibility (selanjutnya disingkat CSR) atau dana tanggung jawab sosial perusahaan. Dana CSR ini memang identik dengan dana sosial atau shadaqah perusahaan untuk masyarakat. Pengelolaan dana CSR ini pun bekerjasama dengan LAZ yang dikelola secara swadaya masyarakat, seperti LAZ PT Semen Indonesia yang mengaku bekerja sama dengan LAZ BMH Gresik dalam penyaluran dana CSR.

Kerjasama penyaluran dana CSR PT Semen Indonesia ini dibenarkan oleh pengurus $\mathrm{BMH}$ Cabang Gresik dan tertuang dalam Buletin Mulia, dengan program pengadaan sumur air bersih bagi warga Benjeng yang bermukim di perbatasan Surabaya Barat dan Gresik. BMH Surabaya juga membenarkan kerjasama pengelolaan CSR dengan PT CIMB Niaga Syariah dan BUMN PT Telkomsel untuk program beasiswa. ${ }^{38}$ Sementara Laporan YDSF tidak mengelola dana CSR. ${ }^{39}$ Namun, pengurus LAZ BMH menolak mengkategorikan dana CSR sebagai bagian dari zakat perusahaan. Hal ini didasari pemikiran bahwa dana zakat harus memiliki akad yang jelas dalam pembayarannya (baik zakat perseorangan maupun zakat perusahaan) sementara akad antara LAZ BMH dan perusahaan adalah penyaluran dana CSR. Pengurus LAZ BMH mengkategorikan dana CSR sebagai dana sosial/ amal biasa yang memang dapat dikategorikan shodaqoh. Permasalahan akad pemberian yang tidak dijelaskan sebagai zakat sangat besar dampaknya sebab jika dana diakadkan sebagai zakat statusnya menjadi hak milik lembaga pengelola zakat. Pemberi zakat tidak berhak menentukan kepada siapa dana itu akan disalurkan. Lembaga pengelola zakatlah yang akan mengatur penyaluran kepada delapan golongan asnaf. Sementara, akad BMH dengan LAZ penyalur dana CSR disertai kesepakatan mengenai program yang akan dijalankan dalam penyaluran dana CSR. Hal ini tidak memenuhi ketentuan penyaluran zakat sebab penyaluran zakat harus diutamakan pada delapan asnaf dengan prioritas urutan yang telah ditentukan. ${ }^{40}$

Berbeda dengan LAZ PT Semen Indonesia yang bekerja sama dengan LAZ swadaya masyarakat dalam pengelolaan dana CSR-nya, LAZ BTN Syariah dan LAZ BMI mengelola dana CSR-nya sendiri. Dana CSR BMI digunakan untuk mendukung program kesehaan operasi katarak gratis ${ }^{41}$. Sementara BTN Syariah menyalurkan dana CSR-nya di bidang kesehatan dan kemitraan. ${ }^{42}$

Permasalahan zakat perusahaan ini menjadi menarik pula sebab berdasarkan diskusi dengan Joko, PNS Bagian Hukum Pemerintah Kota Bangkalan masih mempertanyakan apakah perusahaan merupakan subyek wajib zakat. Menurut pendapat Joko, wajib zakat adalah muslim secara perseorangan. Hal ini dibantah oleh pengurus LAZ BMH bahwa setiap penghasilan dari ataupun dikenai zakat. Oleh karena itulah, obyek zakat dapat diperluas pada zakat pertambangan, zakat perniagaan, zakat perusahaan, zakat pertanian di samping zakat profesi. Oleh karena itu, dapat disimpulkan bahwa salah satu alasan tidak efektifnya penarikan zakat perusahaan adalah pemahaman mengenai kewajiban pembayaran zakat perusahaan yang masih kurang. Hal ini disebabkan regulasi pemerintah mengenai wajib zakat pun tidak tegas dan tidak ada upaya kampanye sadar zakat. Selain itu, zakat perusahaan harus pula benturan dengan konsep CSR/tanggung jawab sosial perusahaan. Kenyataannya, perusahaan cenderung menunaikan CSR namun tidak membayarkan zakat perusahaan sekalipun itu bank syariah. Kewajiban CSR memang berakibat beban ganda perusahaan dalam membayar

Laporan Bulanan Baitul Maal Hidayatullah dalam Buletin Mulia yang telah diperjelas melalui wawancara dengan Supendi, Pengurus Baitul Maal Hidayatullah Surabaya dan Gresik, 10 Oktober 2013.

Laporan Keuangan Yayasan Dana Sosial Al-Falah Tahun 2012 dan Laporan Penerimaan Bulanan Tahun 2013.

4 Diolah dan disimpulkan berdasarkan hasil wawancara dengan Supendi, Pengurus Baitul Maal Hidayatullah Surabaya, 10 Oktober 2013.

41 Laporan Pengurus LAZ Bank Muamalat Indonesia (BMI) Kantor Cabang Surabaya Darmo didukung pengamatan lapangan penyaluran CSR BMI.

42 Keterangan dari Pengurus LAZ BTN Syariah didukung Laporan Tahunan BTN Syariah 2012. 
zakat dan CSR. Sebetulnya konsep ini dapat berjalan seiring jika perusahaan mengalokasikan dana CSR dan menyisihkan 2,5\% dari dana tersebut khusus diniatkan sebagai zakat. Konsekuensinya memang perusahaan boleh mengatur penyaluran dana tersebut melainkan murni menjadi hak pengelolaan BAZNAS/LAZ. Hal ini tentu tidak mudah sebab pelaksanaan penyaluran CSR selalu diiringi permintaan seremonial dan dokumentasi sebagai bentuk laporan sekaligus promosi perusahaan. ${ }^{43} \mathrm{Oleh}$ karena itu, perlu pengaturan sinergi antara insentif pengaturan antara kewajiban mengeluarkan CSR dan zakat perusahaan harus ada. Kelemahan konsep CSR adalah hanya berlaku bagi Perseroan Terbatas, badan hukum/badan usaha lainnya tidak termasuk di dalamnya. Artinya, konsep zakat perusahaan lebih universal untuk semua usaha. Keberhasilan proses penarikan zakat perusahaan akan berdampak pada pemasukan negara. Jumlahnya yang relatif lebih besar dari zakat penghasilan individu dapat dipergunakan secara maksimal untuk kepentingan pemerataan pendidikan, ekonomi, pengentasan kemiskinan.

\section{Kesimpulan}

Berdasarkan uraian di atas, kesimpulan yang dirumuskan adalah yang pertama pengelolaan zakat oleh Badan Amil Zakat dan Lembaga Amil Zakat di wilayah Surabaya dan Gresik masih berorientasi pada zakat perseorangan dengan segmentasi wajib zakat yang berbeda. Kendala dalam penghimpunan dana zakat adalah faktor kesadaran hukum masyarakat atas hukum wajib zakat dan kekurangpahaman pentingnya akad penyerahan harta kepada lembaga penyalur apakah untuk keperluan zakat, infaq atau shodaqoh. Akad penyerahan harta akan berpengaruh pada pola penyaluran harta sebab zakat wajib

diberikan pada delapan asnaf penerima zakat. Selain itu, ketidakjelasan akad akan berakibat belum gugurnya kewajiban membayar zakat. Kesimpulan yang kedua yakni Bank Muamalat Indonesia dan BTN Syariah, PT Semen Indonesia merupakan contoh perusahaan yang memiliki lembaga amil zakat (LAZ). Meskipun demikian, LAZ perusahaan tidak mengelola zakat perusahaan melainkan mengelola zakat, infaq, shodaqoh dari, karyawan, direksi dan/ atau nasabah (bank). Badan Amil Zakat dan Lembaga Amil Zakat yang menjadi obyek penelitian juga menegaskan tidak pernah mengelola zakat perusahaan. Namun, LAZ PT Semen Indonesia, Gresik turut mengelola dana CSR perusahaan yang bekerja sama dengan LAZ Baitul Maal Hidayatullah Gresik. Namun, penyaluran dana CSR ini tidak dapat dikategorikan sebagai zakat perusahaan sebab tidak ada akad pembayaran zakat dan status penyaluran dana CSR dilakukan sesuai program perusahaan bersinergi dengan LAZ. Sementara itu, status dana zakat adalah milik LAZ dan menjadi hak LAZ mengelolanya untuk kepentingan delapan asnaf yang berhak menjadi penerima zakat. Tidak adanya perusahaan yang menunaikan zakatnya merupakan indikasi kurangnya pemahaman terhadap hukum zakat dan lemahnya regulasi pemerintah mengenai pemberdayaan zakat. Untuk itu, pemerintah beserta BAZNAS dan LAZ perlu mengampanyekan kewajiban zakat bagi perusahaan khususnya yang berbasis syariah dan BUMN. Kemudian saran yang kedua yakni model regulasi pengelolaan zakat perusahaan perlu dirumuskan dengan didukung kesadaran perusahaan bahwa zakat merupakan kewajiban yang sebaiknya tidak diseremonialkan penyerahannya dan pendistribusiannya harus diserahkan delapan golongan mustahik zakat.

\section{DAFTAR PUSTAKA}

\section{A. Buku}

Antonio, Muhammad Syafi'i, 2001, Bank Syariah: Dari Teori ke Praktik, Gema Insani Press dan
Tazkia Cendikia, Jakarta

Arifin, Zainul, 2002, Dasar-Dasar Manajemen

Bank Syariah, Alfabet, Jakarta.

43 Kerangan hasil wawancara dengan Supendi, pengurus BMH Cabang Surabaya, Agustus 2013. 
Punch, Keith F., 1998, Introduction to Social Research Qualitative and Quantitative Approaches, Saga Publications, London.

Sudharsono, Heri, 2003, Bank dan Lembaga Keuangan Syariah: Deskripsi dan Ilustrasi, Ekonisia, Yogyakarta.

Sunggono, Bambang, 2005, Metode Penelitian Hukum, Raja Grafindo Persada, Bandung

Yaqin, Anwarul, 2007, Legal Research and Writing, Lexis Nexis, Kelana Jaya, Selangor.

\section{B. Artikel dalam Antologi}

Afdol, 2006, Kewenangan Pengadilan Agama Berdasarkan Undang-undang No. 3 Tahun 2006 \& Legislasi Hukum Islam di Indonesia, Airlangga Universiti Press, Surabaya $\backslash$

Hamid, Suhaila Abdul, 2007, "The Zakat and Tax Practices for Individuals in Malaysia dalam The Developmet of Economics and Muammalat Practices", dalam Nik Salida Sulaiha NIk Saleh, The Developmet of Economics and Muammalat Practices, Penerbit Universiti Sains Islam Malaysia (USIM), Bandar Baru Nilai.

Inoed, Amiruddin, et al., 2005, Anatomi Fiqh Zakat: Potret\&Pemahaman Badan Amil Zakat Sumatera Selatan, Pustaka Pelajar, Yogyakarta

Nawai, Norhaziah binti, dan Ainulashikin binti Marzuki, "The Role of Zakat in Developing Muslim Economy" dalam Nik Salida Sulaiha NIk Saleh, The Developmet of Economics and Muammalat Practices, Penerbit Universiti Sains Islam Malaysia (USIM), Bandar Baru Nilai.

Qardawi, Yusuf, 1996, Hukum Zakat: Studi Komparatif Mengenai Status dan Filsafat Zakat Berdasarkan Qur'an dan Hadis, (terjemah Salamun Harun, dkk), Pustaka Litera AntarNusa dan Mizan, Bogor

\section{Jurnal Penelitian}

Asnawi, Eddy, "Prinsip Bernegara dalam Islam," Jurnal Hukum Respublika: Menegakan
Demokrasi dan Keadilan, Vol. 9, No.1, Desember 2009.

Fauzan, Encik Muhammad, "The Dilemma of The Position of Islamic Law and Its Existence in Indonesia Legal System", Rechtidee: Jurnal Hukum, Vol. 6, No. 1, Juli 2010.

Purbasari, Indah, "Resurrection of Islamic Law in Indonesia", Rechtidee: Jurnal Hukum, Vol. 2, No. 2, Desember 2007.

"The Implementation of Akad Wadiah and Mudharabah in Islamic Banking of Indonesia and Malaysia", Rechtidee: Jurnal Hukum, Vol. 6, No. 2, Desember 2010.

\section{Sumber Internet}

Pusat Badan Amil Zakat Nasional, "Laporan Rekapitulasi Penerimaan Zakat Per Oktober 2012", http://pusat.baznas.go.id/, diakses 1 November 2013.

\section{E. Hasil Penelitian}

Apriliyanto, Tri, 2007, Pelaksanaan Pertanggungjawaban Badan Amil Zakat Kota Surabaya Dalam Pengolahan Zakat: Tinjauan UU No.38 Tahun 1999 Tentang Pengolahan Zakat, Skripsi, Fakultas Hukum Universitas Trunojoyo, Bangkalan.

\section{F. Peraturan Perundang-Undangan}

Undang-Undang Nomor 23 Tahun 2011 tentang Pengelolaan Zakat (Lembaran Negara Republik Indonesia tahun 2011 Nomor 115).

\section{G. Sumber Lain}

Al-Quran, Terjemahan Al-Quran, Departemen Agama Republik Indonesia.

Laporan Bulanan Baitul Maal Hidayatullah dalam Buletin Mulia.

Laporan Keuangan Yayasan Dana Sosial Al-Falah Tahun 2012

Laporan Penerimaan Bulanan Yayasan Dana Sosial Al-Falah Tahun 2013.

Laporan Pengurus LAZ Bank Muamalat Indonesia (BMI) Kantor Cabang Surabaya Darmo Laporan Tahunan BTN Syariah 2012. 